\title{
A new species of Scapholeberis Schoedler, 1858 (Anomopoda: Daphniidae: Scapholeberinae) from the Colombian Amazon Basin highlighted by DNA barcodes and morphology
}

\author{
Camilo Andrade-Sossa ${ }^{1}$, Lorena Buitrón-Caicedo ${ }^{1}$, Manuel Elías-Gutiérrez $^{\text {Corresp. } 2}$ \\ ${ }^{1}$ Grupo de Estudios en Recursos Hidrobiológicos Continentales. Departamento de Biología, Universidad del Cauca, Popayán, Colombia \\ 2 Departamento de Sistemática y Ecología Acuática, El Colegio de la Frontera Sur, Chetumal, Quintana Roo, México \\ Corresponding Author: Manuel Elías-Gutiérrez \\ Email address: melias@ecosur.mx
}

Background: The Amazon basin is recognized as one of the most complex and species-rich freshwater environments globally. The diversity of zooplankton here remains unknown, with many species undescribed.

Methods: Here, we describe a new species of Scapholeberis Schoedler, 1858 (Cladocera: Anomopoda: Daphniidae: Scapholeberinae) from the Colombian Amazon Basin, collected with recently designed light traps. The description is based on detailed morphology (based on SEM and light microscopy) of parthenogenetic females, ephippial females, males, and molecular data based on the COI gene.

Results: Scapholeberis yahuarcaquensis n. sp. has a combination of characters present in Scapholeberis kingi Sars, 1888 and Scapholeberis armata freyi Dumont \& Pensaert, 1983. These are a trilobate rostrum, with the middle lobe well developed with sides straight to relatively rounded, the presence of an elongated slit frontal head pore, a dorsal pore in the juncture of the cephalic shield and the valves, and a single denticulate membrane at the posterior rim of the valves, with stronger setae in the last third. The unique characters of the parthenogenetic females are ventral sucker with delicate triangles. Each has a filament-like projection in the lamellae's inner side and an external section forming convex folds with denticle-like projections in the middle zone of the sucker-plate. There is a peculiar pitted sculpture in the ephippial females and a strong projection in the front of it. The male hook on the limb I with a blunt tip, a quirky lamella-like outgrow in the proximal side, and a paddle with well-developed spines scattered on its surface. The ventral sucker-lamellae in the male is much more developed than the female. The COI gene sequences showed an interspecific mean genetic divergence of $16.4 \%$ between $S$. yahuarcaquensis $n$. $s p$. and the closest species $S$. freyi from Mexico, supporting our results. A coalescence analysis and Barcode Index Number also support the new species based on the DNA sequences. New methods of collecting and integrative biology will give important support to recognize the fauna from the Amazon Basin, one of the most important sources of fresh water in the world that remains unknown in many respects. 
A new species of Scapholeberis Schoedler, 1858 (Anomopoda: Daphniidae: Scapholeberinae) from the Colombian Amazon Basin highlighted by DNA barcodes and morphology

Camilo Andrade-Sossa ${ }^{1}$, Lorena Buitrón-Caicedo ${ }^{1}$, Manuel Elías-Gutiérrez,2*

*Corresponding author: 
33 Abstract

34

Background: The Amazon basin is recognized as one of the most complex and species-rich freshwater environments globally. The diversity of zooplankton here remains unknown, with many species undescribed.

Methods: Here, we describe a new species of Scapholeberis Schoedler, 1858 (Cladocera:

Anomopoda: Daphniidae: Scapholeberinae) from the Colombian Amazon Basin, collected with recently designed light traps. The description is based on detailed morphology (based on SEM and light microscopy) of parthenogenetic females, ephippial females, males, and molecular data based on the COI gene.

Results: Scapholeberis yahuarcaquensis n. sp. has a combination of characters present in Scapholeberis kingi Sars, 1888 and Scapholeberis armata freyi Dumont \& Pensaert, 1983. These are a trilobate rostrum, with the middle lobe well developed with sides straight to relatively rounded, the presence of an elongated slit frontal head pore, a dorsal pore in the juncture of the cephalic shield and the valves, and a single denticulate membrane at the posterior rim of the valves, with stronger setae in the last third. The unique characters of the parthenogenetic females are ventral sucker with delicate triangles. Each has a filament-like projection in the lamellae's inner side and an external section forming convex folds with denticle-like projections in the middle zone of the sucker-plate. There is a peculiar pitted sculpture in the ephippial females and a strong projection in the front of it. The male hook on the limb I with a blunt tip, a quirky lamella-like outgrow in the proximal side, and a paddle with well-developed spines scattered on its surface. The ventral sucker-lamellae in the male is much more developed than the female. The COI gene sequences showed an interspecific mean genetic divergence of $16.4 \%$ between $S$. 
55

yahuarcaquensis n. sp. and the closest species $S$. freyi from Mexico, supporting our results. A coalescence analysis and Barcode Index Number also support the new species based on the DNA sequences. New methods of collecting and integrative biology will give important support to recognize the fauna from the Amazon Basin, one of the most important sources of fresh water in the world that remains unknown in many respects.

\section{Introduction}

Scapholeberis Schoedler, 1858 is one of the two genera of the Scapholeberinae Dumont \& Pensaert, 1983 included in the Daphniidae Straus, 1820. They are small cladocerans adapted to live in the hyponeuston of the freshwater ecosystems. A peculiar adaptation of this genus is the ventral sucker to attach the animal by superficial tension below the water surface. This structure was described by the first time in detail with scanning electron photographs by Dumont \& Pensaert (1983) for different members of the Scapholeberinae.

It seems that these daphniids have a long history living suspended below the surface film of the water, with the oldest Scapholeberis-like member found in amber dated from the Lower Cretaceous (c. 100 My before present) (Flössner \& Fryer 2016). However the affinity of this specimen was doubted by Van Damme \& Kotov (2016) without analyzing the original material. Out of discussions, if we consider a long history of the genus, it is unlikely to have only eight species known worldwide. For example, Quiroz-Vazquez \& Elías-Gutiérrez (2009) highlighted the slow advance in the taxonomic knowledge of Scapholeberis. They described the last member of this genus from Mexico by using integrative taxonomy. It was related to Scapholeberis armata freyi Dumont \& Pensaert, 1983, now recognized as Scapholeberis freyi by Kotov et al. (2013) and Taylor et al. (2020). 
77 Recently Taylor et al. (2020) published a phylogeographic analysis of Scapholeberinae based in three RNA regions of the mitochondrial genome showing 17 divergent lineages across the world. Nevertheless, South American fauna was poorly represented in their dataset. In the particular case of the Amazon basin, no barcoding study exists related to zooplankton. However, it is a unique enormous eco-region with many endemic species (i.e., Rowe et al., 2007). Currently, while we were preparing a baseline for several lakes and rivers from the Colombian Amazon Basin, we found an intriguing Scapholeberis with some resemblance to Scapholeberis freyi (Dumont \& Pensaert, 1983). In the checklists and data published from South America there are five members of this genus (De los Rios \& Kotov 2015; Kotov \& Fuentes-Reines 2015), one of them identified as Scapholeberis armata freyi in Brazil (De Abreu 2016; Elmoor-Loureiro 2000), and represented by the sequence KU315490.1 in GenBank under the name $S$. armata freyi.

Thi work aims to describe a new species based on all possible morphological characters, and molecular data, based on COI sequences and a comparison of them with other species from the world.

\section{Material and methods}

On May 2 and 3 of 2018, we deployed a light trap and carried out several horizontal tows with a plankton net of $50 \mu \mathrm{m}$ mesh in several locations along the Amazonas basin from Colombia. The light trap was the same as described by Montes-Ortiz \& Elías-Gutiérrez (2018), and it worked only three to four hours to avoid oversaturation and immediate death of the collected material. We noticed that the species from this region have a strong positive phototaxis. Specimens were preserved according to Elías-Gutiérrez et al. (2018), and all of them were sorted under a stereomicroscope. Part of the material was processed for molecular analyses, and other specimens were used for a detailed morphological study. 
100 Field permit for collections with non-commercial scientific research purposes was issued by

101 Autoridad Nacional de Licencias Ambientales (ANLA) (Resolution \#0152).

102 Morphological analysis

103 For morphology analyses, we mounted the dissections in a mixture of glycerol and formaldehyde

104 (1:1) on a slide and covered them with a coverslip. The slide was sealed with Depex mounting

105 medium. We analyzed all specimens under a microscope with phase contrast and Normanski

106 microscopy (BX51 Olympus). All limbs were drawn using a camera lucida attached to the

107 microscope and digitized directly with a CINTIQ tablet (WACOM) using Adobe Photoshop PS4.

108 Part of the material was prepared using the drying method with Hexamethyldisilazane (HDMS),

109 to avoid deforming of the delicate membranes of the ventral sucker. They were passed in gradual

110 concentrations, increasing $10 \%$ each time, diluted with $100 \%$ ethanol, from $30 \%$ to $100 \%$. This

111 work was done after dehydration of the specimens to absolute ethanol. Finally, after evaporation

112 of the HDMS, in the final step, they were gold coated. All photographs and observations were

113 made with a scanning electron microscope (SEM) JEOL- JSM6010 at the Chetumal Unit from El

114 Colegio de la Frontera Sur, Mexico.

\section{DNA extraction and amplification}

116 DNA was extracted, and thermocycling was performed accordingly to the methods provided by

117 Elías-Gutiérrez et al. (2018). PCR products were visualized on a 2\% agarose gel using an E-Gel

11895 well Pre-cast Agarose Electrophoresis System (Invitrogen) and those showing a band, as a

119 result of the PCR product, were selected for sequencing.

\section{Sequencing and data analysis}

121 PCR products were sequenced bi-directionally with the methods suggested by Hajibabaei et al.

122 (2005), using M13F and M13R primers. Sequences were edited accordingly with the methods 
123 provided by Elías-Gutiérrez et al. (2018). Sequence data, electropherograms, trace files, primer

124 details, photographs, and collection localities for all specimens are available within the dataset

125 Scapholeberis from Amazon Basin (DS-SCAMACOL) in Barcode of Life Database (BOLD,

126 www.bodsystems.org). All data were analyzed with the tools provided on BOLD for control of

127 quality (Ratnasingham \& Hebert 2007).

128 In all cases, the vouchers were deposited at the Museo de Historia Natural, Instituto de Ciencias

129 Naturales, Universidad Nacional de Colombia, and the Reference Collection at El Colegio de la

130 Frontera Sur, Unidad Chetumal (Access Numbers ECO-CH-Z 10336-10338).

131 With all sequences from the Amazon, we prepared a dataset with the name DS-SCAMACOL

132 Scapholeberis from Amazon Basin in BOLD database (DOI: 10.5883/DS-SCAMACOL).

133 Additionally, these sequences were uploaded to GenBank (Accession Numbers: MT607962-

134 MT607970).

135 We used the Alignment Transformation Environment (ALTER, http://www.sing-

136 group.org/ALTER/), to get representative haplotypes of all the genetic variants of COI within

137 and between species (Supplementary File 1). We applied MrBayes Vers. 3.2.5 and jModelTest

1382.1 .10 for calculations of the phylogeny. The best fit substitution model was TIM2+G, and it was

139 replaced by GTR $+\mathrm{G}$ in MrBayes along with $1 \mathrm{M}$ generations to obtain a tree. The Generalized

140 Mixed Yule Coalescent (GMYC) method was applied as Gutiérrez Aguirre et al. (2020)

141 suggested to delimit the species. Finally, with the groups delimited by the GMYC technique, we

142 calculated the mean estimates of evolutionary divergence over sequence pairs between groups.

143 Analyses were conducted using the Kimura 2-parameter model (Kimura 1980) in MEGA 7

144 (Kumar et al. 2016). The standard error of the estimates was obtained by a bootstrap procedure

145 (500 replicates). 
146 Nomenclatural acts

147 'The electronic version of this article in Portable Document Format will represent a published 148 work according to the International Commission on Zoological Nomenclature (ICZN), and hence 149 the new names contained in the electronic version are effectively published under that Code from 150 the electronic edition alone. This published work and the nomenclatural acts it contains have

151 been registered in ZooBank, the online registration system for the ICZN. The ZooBank Life

152 Science Identifiers (LSIDs) can be resolved and the associated information viewed through any 153 standard web browser by appending the LSID to the prefix http://zoobank.org/. The LSID for 154 this publication is: urn:1sid:zoobank.org:pub:5CF5417E-A35F-42BC-97D4-5BB4AD6D6259.

155 The online version of this work is archived and available from the following digital repositories:

156 PeerJ, PubMed Central and CLOCKSS'

157 Results

158 Systematics

159 Class Branchiopoda Calman, 1909

160 Order Anomopoda Sars, 1865

161 Family Daphniidae Straus, 1820

162 Subfamily Scapholeberinae Dumont \& Pensaert, 1983

163 Genus Scapholeberis Schoedler, 1858

164 Scapholeberis yahuarcaquensis n. sp.

165 Type Locality: Quebrada and lakes system Yahuarcaca, Amazon basin. A system of 166 interconnected blackwater streams and lakes, with periodic floodings of white-water from the 167 Amazon River. Three localities in this interconnected system, located at $4.193640^{\circ} \mathrm{S}$, $16869.954465^{\circ} \mathrm{W}$ (Yahuarcaca Lake); 4.158175 $\mathrm{S}, 69.968207^{\circ} \mathrm{W}$ (Quebrada Yahuarcaca, Flooded 
169 Trees) and $4.157807^{\circ} \mathrm{S}, 69.967763^{\circ} \mathrm{W}$ (Quebrada Yahuarcaca, near village San Antonio) were

170 positive for this species. From the three, we designate the last as the type locality (Quebrada

171 Yahuarcaca near the village San Antonio).

172 Etymology: This species is named after its terra typica, the Yahuarcaca lakes and stream system

173 in the Amazon basin from Colombia.

174 Holotype: Adult parthenogenetic female in 96\% ethanol with addition of a drop of glycerol,

175 deposited at the Museo de Historia Natural, Instituto de Ciencias Naturales, Universidad

176 Nacional de Colombia. Access number, ICN-MHN-CR 3405.

177 Allotype: One complete male in $96 \%$ ethanol with addition of a drop of glycerol, deposited at

178 the Museo de Historia Natural, Instituto de Ciencias Naturales, Universidad Nacional de

179 Colombia Access number, ICN-MHN-CR 3406

180

Paratypes: Five parthenogenetic females and one ephippial female in $96 \%$ ethanol with addition of a drop of glycerol, deposited at the Museo de Historia Natural, Instituto de Ciencias Naturales, Universidad Nacional de Colombia Access numbers, ICN-MHN-CR 3407 and ICN-MHN-CR 3408. Four parthenogenetic and two ephippial females in $96 \%$ ethanol with addition of a drop of glycerol, one dissected parthenogenetic female in a mix formalin-glycerol, sealed with GURR mounting medium, deposited at El Colegio de la Frontera Sur, Unidad Chetumal, Access numbers ECO-CH-ZPL10336-10337.

187 One male in ethanol with a drop of glycerol deposited at El Colegio de la Frontera Sur, Unidad 188 Chetumal, Access number ECO-CH-ZPL10338.

Diagnosis. Medium-sized daphniids. Length of parthenogenetic females: $541 \pm 13.3 \mu \mathrm{m}(\mathrm{n}=6)$, height $342.6 \pm 23.8 \mu \mathrm{m}(\mathrm{n}=6)$, body ovoid. Ventro-posterior corner of valves angular, forming a 
191 well-defined mucro of medium length (Figures 1A-D). Ephippium slightly reticulated with a

192 strong horse saddle shape and a single egg (Figure 1B). Large and bilaterally ridged head with a

193 flat surface. The head with a strong reticulation (Figure 1E-F), but valves smooth in larger

194 females. Rostrum trilobate, the middle lobe well developed with sides straight to relatively

195 rounded (Figure 1G-H), the frontal head pore with an elongated shape. Antennule short, with

196 nine terminal aesthetascs and a lateral sensory seta (Figure 1H). Antenna with a four-segmented

197 exopod and a three-segmented endopod. Posterior rim of valves with a stronger seta in the last

198 third (Figure 2D), with a single membrane denticulate all its way (Figure 2D-E). The ventral rim

199 of valves infolded, forming an adhesive sucker-plate (Figure 3A), that in the middle zone present

200 lamellae internally forming triangle-like structures ending in three long filaments (Figure 3C-D)

201 and externally have indented convex folds but with spine-like projections in the free border

202 (Figure 3F). Five trunk limbs of general daphnid shape. Endopodite of trunk limb I with a brush-

203 like seta with the fine hairs in the top decreasing in size, giving a finer tip than the base (arrow,

204 Figure 4F). Postabdomen robust, more or less rectangular, with dorsal margin flat and straight, is

205 covered by rows of spinules (Figure 5C). Postabdomen claw with three successive pectens of

206 different sizes on each internal and external margin (Figure 5B-E). Male with ventral sucker-

207 lamellae much more developed than female (Figure 6A) and rectangular shape of the body. Male

208 hook in limb I with a blunt tip and a peculiar lamella-like outgrows in the proximal side. Paddle

209 with well-developed spines scattered on its surface (Figures 6C-D).

210 Description of parthenogenetic female. Head similar to S. duranguensis (see Figures 1E-F).

211 Middle lobe of rostrum well-developed straight to slightly rounded with an elongated slit-pore

212 structure (the so-called frontal head pore) at the tip (Figure 1E-H). Globular eye and round

213 ocellus. 
214 Antennule short and oval with nine terminal aesthetascs cylindrical and different length (Figure

$2151 \mathrm{H} ; 4 \mathrm{~A})$. With a lateral sensory seta of the same size as the aesthetascs.

216 Head smooth in adult females, slightly reticulated in juveniles, delimited by two sclerotized

217 ridges that extend to each side of the head (Figure 2A, arrow in Figure 1A). In the headshield's

218 junction with the valves, there are two small lateral pores on each side (arrow in Figure 2A-B).

219 Valves in juvenile animals sometimes with reticulation, mostly in the posterior-dorsal regions

220 (Figure 1C). Other specimens with a smooth surface (Figure 1D). Adult parthenogenetic females

221 with smooth valves, and some reticulation and parallel lines near the A2 (Figure 1A). The

222 posterior margin of the valves with a single denticulated lamella (Figure 2C), forming in the

223 dorsal side a wider seta (Figure 2D). In the ventral part, near the mucro, the hyaline lamella is

224 formed by a fold of the sucker (Figure 2E). Ventral rim of valves infolded, supplied with

225 lamellae well developed that form an adhesive sucker-plate (Figure 3A). The lamellae in the

226 sucker-plate different in three clearly defined regions: On the posterior side, the lamellae are thin

227 and again cross from side to side the sucker from each valve (Figure 3B). In the middle part of

228 the sucker, the lamellae are divided internally, forming triangle-like structures with three long

229 filaments in the apex (Figure 3C). Anteriorly, the lamellae are denticulated and cross entirely

230 from inside to the border (Figure 3D). In the last third of the sucker, the apex of the lamellae

231 widens in a straight end, with a series of long denticles and a filamentous projection on the inner

232 side (Figure 3E). Externally there are convex folds full of spine-like projections in the free

233 border (Figure 3F).

234 Antenna with four-segmented exopod and three-segmented endopod (Figure 1A-D; 4C).

235 Basipodite thick, with several rows of spines around it, the most proximal bigger, two setae in 
236 the outer side of the base (Figure 4B). In the distal side, there is a pore giving origin a thin seta

237 and a finger-like apical projection (Figure 4D). In the middle of the exopod's insertion and

238 endopod to the basipod, there is a small projection with a seta. First exopod segment with

239 approximately one-third of the length of the second segment. The latter with three setae in the

240 ventral face and a small terminal seta-like projection. Second segment much shorter than the next

241 Last segment longer than the penultimate (Figure 4C). First endopod segment much longer than

242 the other two. First and second endopod segments with a long internal-lateral seta. Antennal

243 formula $0-0-1-3 / 1-1-3$ setae, spines $0-1-0-0 / 0-0-0$.

244 Labrum triangle-like shaped, with the anterior margin pitted, with the tip covered by lines of 245 hairs (Figure 4E).

246 Postabdomen rectangular with ventral margin convex (Figure 5C, 6E). Length approximately

247 three times more than height. Preanal portion approximately one-third of the total length. Ventral 248 face with two lateral rows of four spines, decreasing in size proximally. Dorsal face straight with 249 several rows of strong spines (Fig. 5C).

250 Postabdominal claw shorter than the preanal portion (Figure 5E). With six rows of spinules

251 (pectens) on each claw. On the most outer side, near the base of the claw, there are 4-5 thick and 252 prominent spines forming a group decreasing in size proximally (arrow in Fig. 5E). The basal 253 internal pecten, ascends in a dorsal direction, up to a fifth of the beginning of the medium pecten, 254 which is similar in size and shape of the spines. The medium external pecten starts at the base of 255 the claw and extends to a bit less than half of it. The internal one is similar, but the spines are a 256 little shorter and thinner. The longer external pecten has spines gradually increasing slightly in 257 size, starts at the last third of the mid pecten, and extends to the claw's tip. The internal one starts 
258 with 6-7 single wide spines (arrow) and continues with the spines gradually decreasing in width 259 to the tip.

260 Trunk limb I (P1). Exopod with two unsegmented, apical setae, unequal in size (Figure 7A).

261 With one row of long and thick setulae in the distal two-thirds of both. In the middle of the

262 longer seta, a bunch of short and thick setulae. A long accessory seta at the basal external face of

263 the exopod, with a triangular projection near its base. Endite 4 with three apical setae. The

264 longest seta with short setulae bilaterally arranged from the half to the tip. The second seta about

265 two-thirds as long as the first one and with an apical tuft of long setulae. The third seta is brush-

266 shaped. This seta has at the tip setulae, increasing their length towards one end, giving a peculiar

267 form (Figure 7A, 4F, arrow). Endite 1, and endites 2 and 3 similar to $S$. duranguensis. The most

268 proximal seta shorter and bilaterally setulated. Ejector hooks long, with setulae along their inner

269 side (Figure 4F).

270 Trunk limb II (P2). Exopod, endopod and gnathobase similar to S. duranguensis (Figure 7B).

271 The two appendages found in the base of the exopod in S. duranguensis seem to be absent.

272 Trunk limb III (P3). Exopod also similar to $S$. duranguensis (Figure 7C), except for the

273 following: setae 3 and 4 with fine spines in one face, and the last two thirds with short, strong

274 setae. Seta 4 with a crown of long and thick setae. Endite 1 with long and naked seta and two

275 shorter and bilaterally setulated setae. Endite 2 with two long setulated setae. Endite 3 with one

276 strongly naked chitinized seta and one normal setulated seta. Endite 4 with a similar arrangement

277 as E3, but both elements longer. Gnathobase with 18, bisegmented and thin setae similar in size

278 and shape. At the internal end, there is a lobe with two additional setae. 
279 Trunk limb IV (P4). This limb is similar to other Scapholeberis, in particular, it resembles the

280 detailed description of S. duranguensis by Quiroz Vázquez and Elías Gutiérrez (2009).

281 Trunk limb V (P5). With a long, bisegmented, densely ciliated seta in the endopod (Figure 7E),

282 another thinner and shorter behind it. A tiny structure at the base of the seta with a bunch of

283 setulae and distal tip narrower is approximately one-third of the total long seta. Exopod with two

284 shorter setulated setae. There is a long setulated distal seta.

285 Description of ephippial female. Carapace less massive than egg-carrying females (length $286527.7 \pm 31.6 \mu \mathrm{m}, \mathrm{n}=3$ ), height $310.5 \pm 39.5$ (Figure 1B). Ephippia thick, convex in the dorsal keel, 287 with a strong projection towards the front and the back. The surface of the ephippia pitted and covering about $2 / 3$ of the whole carapace. The ephippial females have the carapace brown and dark brown towards the dorsum. All other characters are similar to the parthenogenetic females.

Description of male. With strong sexual dimorphism, males are smaller with length $371 \pm 11.7$ $\mu \mathrm{m}(\mathrm{n}=3)$, height $188 \mu \mathrm{m}(\mathrm{n}=2)$, rectangular in shape, similar to immature females (Figure 1CD), but the lamellae of the sucker much more developed than in females (Figure 6A, arrow). A1 with longer asthetascs (Figure 6B) and P1 strongly modified with a hook in limb I. The hook has a blunt tip, and a triangular lamella-like outgrows in the proximal side (Figure 6D). Copulatory pad with strong spines arranged in lines, two parallel in distal part (Figure 6D). apparent (Figure 6E).

Postabdominal claw similar to females, but the most internal pecten lacks the single robust spines. The group spines on the outer side of the basis of the claw have only three spines more strongly fused than in females (Figures 6E-F). 
301 All other characters are similar to females.

302 DNA Sequences (CO1):

303 We got nine almost identical sequences, representing two possible haplotypes, with an overall

304 distance of $0.3 \%$ from parthenogenetic and ephippial females from two close points in the

305 Amazon basin (see type material). All of them are in the dataset DS-SCAMACOL in BOLD. A

306 consensus sequence for this species is:

307

308

309

310

311

312

313

314

315

316

317

318

319

320

321

322

323

324

325

326

327

328

329

330

\begin{abstract}
CATTATATTT
TAGTATGCTA

ATGATCAGAT

TTCTTTATGG

TCCTTTAATG

TAAGTTTTTG

GCGGTAGAAA

GGCGGGAATC

TTCATTTGGC

ACTATTATTA

ATTTGTGTGG

CTGTTTTAGC

ACCTCGTTTT
\end{abstract}

\begin{abstract}
TATTTTTTGG
ATTCGGGCAG

TTATAACGTA

TTATACCAAT

TTAGGTGCTC

ATTTCTTCCT

GTGGGGCTGG

GCTCACGCTG

AGGGATTTCT

ATATACGATC

GCGGTAGGAA

AGGGGCAATT

TTGACCCGGC
\end{abstract}

\begin{abstract}
TGTTTGATCT
AGTTGGGCCA

GTTGTTACAG

TATAATTGGA

CCGATATAGC

CCTGCCTTAA

AACTGGCTGA

GAGCCTCAGT

TCTATTTTAG

GGAAGGAATG

TCACAGCTCT

ACGATGCTTC

TGGAGGAGGA
\end{abstract}

\begin{abstract}
GGTATAGTTG
GGCTGGTACT

CCCATGCTTT

GGTTTTGGGA

TTTTCCTCGA

CTCTTCTTTT

ACTGTTTATC

CGATTTAAGA

GAGCTGTTAA

TCTCTAGATC

CCTTCTACTT

TAACGGATCG

GATCCAATTC
\end{abstract}

$\begin{array}{ll}\text { GGACCGCTCT } & 50 \\ \text { TTAATTGGGG } & 100 \\ \text { TGTAATAATT } & 150 \\ \text { ACTGGCTAGT } & 200 \\ \text { TTAAATAACC } & 250 \\ \text { AGTTGGAGGG } & 300 \\ \text { CTCCTTTATC } & 350 \\ \text { ATCTTCTCCC } & 400 \\ \text { TTTCATTACT } & 450 \\ \text { GAATTCCATT } & 500 \\ \text { TTAAGTCTTC } & 550 \\ \text { GAACTTAAAC } & 600 \\ \text { TCTATCAACA } & 650\end{array}$

GC\% of the first and third codon positions were similar, with a percentage ranging from 53.00 to 53.46 and 25.46 to 25.93 . A $\%$ and $\mathrm{T} \%$ gave the main total variation.

DNA analyses revealed 11 clades with the COI gene (Figure 8). Clade for S. yahuarcaquensis n.sp. is well supported by the Bayesian analyses of coalescence (Supplementary File 2) and the BIN number (ADN0437) (Ratnasingham \& Hebert 2013). The closest species to $S$.

yahuarcaquensis n. sp. is $S$. freyi from Mexico with a mean distance $16.4 \%$ divergence, followed by Scapholeberis sp. (Chihuahua) and S. duranguensis Quiroz-Vázquez \& Elías-Gutiérrez, 2009, both from Mexico with $18.4 \%$ and $18.7 \%$ divergence (Table 1). A big not solved group is the northern America named Scapholeberis armata group, represented by four BINS distributed from the north of the United States to Canada and Alaska. All other Scapholeberis from the 
331 world form definite clades, but the species name in some cases as Scapholeberis rammneri s.1.

332 require further studies.

\section{Discussion}

334 Records of Scapholeberis species in America are mainly from Mexico, the United States, and

335 Canada. In South America, there were only five species and one subspecies registered: 1.

336 Scapholeberis armata Herrick, 1882, is a Nearctic species reported in Colombia for the Andean

337 region (Kotov \& Fuentes-Reines 2015). 2. Scapholeberis mucronata (O. F. Müller, 1776)

338 registered for the Nearctic, Palearctic, Neotropical regions (Kotov et al. 2013) and Colombia is

339 cited in the Caribbean (Kotov \& Fuentes-Reines 2015). 3. Scapholeberis kingi Sars, 1888, a

340 Palearctic species, according to De los Rios \& Kotov (2015). The neotropical records probably

341 correspond to $S$. cf. rammneri Dumont \& Pensaert (1983) (Taylor et al. 2020). 4. S. rammneri,

342 which, according to Taylor et al. (2020), is widespread in South America, 5. Scapholeberis

343 spinifera (Nicolet, 1849) of the most southern portion of South America (Taylor et al. 2020). 6.

344 Scapholeberis armata freyi Dumont \& Pensaert, 1983, listed as Scapholeberis freyi Dumont \&

345 Pensaert, 1983 by Kotov et al. (2013), and with Nearctic and Neotropical distribution.

346 A problem is to collect these hyponeuston taxa with conventional methods as plankton tows that

347 usually pass below the surface of the water. They are considered a "bycatch" from other methods

348 targeting immature mosquitoes (Taylor et al., 2020). We found that Scapholeberis has a strong

349 positive phototaxis on all stages of the life cycle, particularly males and ephippial females are

350 scarce in "normal" sampling, possibly due to their rarity in the environment. After only three

351 hours of work with the light traps, we obtained an ample sample with positive records in three

352 localities. These samples had not only Scapholeberis representatives. It was a real "soup" of 
353 zooplankton. We believe that using light traps will help understand the diversity of zooplankton

354 in this important region.

355 Of the known taxa for South America, only in two cases material collected in the Neotropical

356 zone has been included for the descriptions, S. spinifera, and S. freyi, the latter from the material

357 of Paraguay from Daday's collection (Dumont \& Pensaert, 1983). In all the other cases, the

358 reports in South America have been assumed morphologically consistent with the species

359 described for other latitudes or other continents.

360 We consider that detailed morphological analysis and the use of molecular tools, like DNA

361 barcoding, will help to uncover the real identity of all these species, as the case presented here or

362 with Scapholeberis duranguensis Quiroz-Vazquez \& Elías-Gutiérrez 2009, which was initially

363 cited as S. rammneri by DeWaard et al. (2006) and for which the closest species was $S$. freyi. The

364 general mixed Yule coalescent (GMYC) model used as a species delimitation method has been

365 tested in other crustaceans as copepods (Gutiérrez-Aguirre et al., 2020). It has been consequent

366 with other methods as the BIN system and morphology, giving strong support to the modern

367 description of species.

368 Scapholeberis freyi is distributed from Florida to the south coast of the Gulf of Mexico in the

369 neotropics. In South America, this species has been reported in Brazil (Elmoor-Loureiro 2000)

370 and Paraguay (Dumont \& Pensaert 1983 and references therein). De Abreu (2016) compared a

371 sequence (KU315490) from Minas Gerais (Brazil) with all available sequences in BOLD and

372 GenBank, and she found sharp divergences with all of them. She concluded that possibly her

373 specimen belongs to a different species, but the name found in GenBank still is $S$. armata freyi

374 (see https://www.ncbi.nlm.nih.gov/nuccore/KU315490.1). Our sequences were grouped with this 
375 one (Figure 8, Supplementary File 2), so we can conclude that these specimens were conspecific

376 and the distribution of the $S$. yahuarcaquensis n.sp. extends beyond the Amazon basin. In total,

377 three haplotypes represented this species (Supplementary File 2). This sequence had only $92 \%$

378 similarity with the closest match of Taylor et al. (2020) comparisons with COI.

379 A comparison with $S$. freyi, the closest relative of $S$. yahuarcaquensis n.sp. reveals important

380 differences in morphology: rostrum less wide and almost straight in adult females with an oval

381 pore (similar to $S$. kingi, see Plate 3-7 in Dumont \& Pensaert, 1983). The dorsal pores are at the

382 juncture of the cephalic shield and valves as in S. kingi from Australia (Dumont \& Pensaert,

383 1983). The number of spines in the base of the claw at the outer side is more numerous.

384 The sucker is quite peculiar in S. yahuarcaquensis n. sp., with the lamellae forming delicate

385 triangles with filament-like projections (Figure 3C). Another feature unique in the sucker region

386 is the external lamellae with denticle-like projections. The male has a strong development of the

387 sucker-lamellae in the anterior end and diminishing in size posteriorly (see Figure 6A) opposite

388 as described for the male of $S$. freyi by Dumont \& Pensaert (1983). All setae and aesthetascs

389 have a pore in the A1. The hook in male P1 is not sharply recurved as S. freyi, and the pad has a

390 unique armature with the spine-like projections as described previously.

391 Although some similarities are found between $S$. kingi from the old continent and $S$.

392 yahuarcaquensis from South America, differences are given by the middle lobe of the rostrum

393 almost straight, the ventral sucker, valves with no sculptures in adult females, with a single

394 hyaline membrane with different arrangement and not broad. The male has a middle lobe in the

395 rostrum wide and flat in S. yahuarcaquensis, not short. The hook in P1 has four lamella-like 
396 projections triangle-shaped, not two strong teeth, and several rows of spinules in the pad and the

397 ventral sucker is entirely different, much more developed.

\section{Conclusions}

399 This study is an example of a description based on all stages of the life cycle of a cladoceran. In

400 most taxonomical analyses, the collection of males or ephippial females is difficult because they

401 are mostly rare. This case is the first of new and exciting discoveries in the Amazon basin by

402 using complementary methods as plankton tows and light traps that never before were used here.

403 Finally, long ago, Dumont \& Pensaert (1983) pointed out that several undescribed species

404 of Scapholeberis await their discovery in South America. We consider that more extensive

405 samplings are urgent in this crucial region to continue the documentation of their biodiversity

406 due that most of their aquatic environments are under a severe threat.

407 Once we have proper documentation in public databases of the species present, we could use

408 new technologies currently available as next-generation sequencing and environmental DNA.

409 Zooplankton community is the first to shift due to any change that could be subtle as the

410 translocation of species or significant as the enrichment of the waters after extensive use of

411 fertilizers, as nowadays occurring in several parts of the Amazon basin.

\section{Acknowledgements}

413 Professor Santiago R. Duque (Instituto Amazónico de Investigaciones [IMANI], Universidad

414 Nacional de Colombia-Amazonian Campus) for his support of field activities in the Amazonian

415 region. Alma Estrella García Morales from Chetumal Node of the Mexican Barcode of Life

416 Network (MEXBOL) performed all DNA analyses. Osvar Cupitra-Gómez, Alberto Moncayo-

417 Fernández, María del Mar Rivera-Portilla and Juan Monteiro kindly assisted us with the field

418 work. The people from the village La Playa supported our work and allowed us to sample in their 
419 region. This work is part of the results of a doctoral thesis, supported by the Universidad

420 Nacional de Colombia, Universidad del Cauca, and ECOSUR to Camilo Andrade Sossa, and it

421 was developed within the framework of an international agreement signed between the last two

422 institutions. ME-G recognizes the Mexican government's efforts to smother all aspects of science

423 progressively, particularly about international cooperation and biodiversity conservation, as a

424 motivation to produce and conclude this work.

\section{References}

426

427

428

429

430

De Abreu CB. 2016. Diversidade genética de cladocera (crustacea: branchiopoda) do sul de Minas Gerais, utilizando DNA barcode como marcador molecular Master of Sciences. Universidade Federal de Alfenas.

De los Rios P, and Kotov AA. 2015. A checklist of Branchiopoda (Anostraca and Cladocera) of Chilean continental waters. Zootaxa 4027:366-388.

\section{DeWaard JR, Sacherova V, Cristescu MEA, Remigio EA, Crease TJ, and Hebert PDN.} 2006. Probing the relationships of the branchiopod crustaceans. Molecular Phylogenetics and Evolution 39:491-502.

Dumont HJ, and Pensaert J. 1983. A revision of the Scapholeberinae (Crustacea: Cladocera). Hydrobiologia:3-45.

Elías-Gutiérrez M, valdez-Moreno M, Topan J, Young MR, and Cohuo-Colli JA. 2018. Improved protocols to accelerate the assembly of DNA barcode reference libraries for freshwater zooplankton. Ecology and Evolution 8:3002-3018.

Elmoor-Loureiro LMA. 2000. Ocorrência de Scapholeberis armata freyi Dumont \& Pensaert (Crustacea, Anomopoda, Daphniidae) no estado de São Paulo, Brasil. Revista Brasileira de Zoologia 17:301-302. 
442 Flossner D, and Fryer G. 2016. An Early Cretaceous anomopod (Crustacea: Branchiopoda)

443

444

445

446

447

448

449

450

451

452

453

454

455

456

457

458

459

460

461

462

463

preserved in amber that reveals an unexpected venture during the evolution of the order. Journal of Natural History 50:1291-1304. 10.1080/00222933.2015.1134693

Gutierrez-Aguirre, M. A., Cervantes-Martinez, A., Elías-Gutiérrez, M., \& Lugo-Vazquez, A. 2020. Remarks on Mastigodiaptomus (Calanoida: Diaptomidae) from Mexico using integrative taxonomy, with a key of identification and three new species. Peerj, 8: e8416. $10.7717 /$ peerj.8416

Hajibabaei M, DeWaard JR, Ivanova NV, Ratnasingham S, Dooh R, Kirk SL, Mackie PM, and Hebert PDN. 2005. Critical factors for assembling a high volume of DNA barcodes. Philosophical Transactions of the Royal Society of London Series B-Biological Sciences 360:1959-1967.

Ivanova NV, DeWaard JR, and Hebert PDN. 2006. An inexpensive, automation-friendly protocol for recovering high-quality DNA. Molecular Ecology Notes 6:998-1002.

Kimura M. 1980. A simple method of estimating evolutionary rate of base substitutions through comparative studies. Journal of Molecular Evolution 16:111-120.

Kotov AA, Forró L, Korovchinsky NM, and Petrusek A. 2013. World checklist of freshwater Cladocera species. http://fada biodiversity be/group/show/17.

Kotov AA, and Fuentes-Reines JM. 2015. An annotated checklist of the Cladocera (Crustacea: Branchiopoda) of Colombia. Zootaxa 4044:493-510.

Kumar S, Stecher G, and Tamura K. 2016. MEGA7: Molecular Evolutionary Genetics Analysis Version 7.0 for Bigger Datasets. Molecular Biology and Evolution 33:18701874.

Peer) reviewing PDF | (2020:06:50124:1:1:NEW 18 Aug 2020) 
464 Montes-Ortiz L, and Elías-Gutiérrez M. 2018. Faunistic survey of the zooplankton community

465 in an oligotrophic sinkhole, Cenote Azul (Quintana Roo, Mexico), using different

466

467 sampling methods, and documented with DNA barcodes. Journal of Limnology 77:428-

468

469

470

471

472

473

474

475

Taylor DJ, Connelly SJ, and Kotov AA. 2020. The Intercontinental phylogeography of neustonic daphniids. Scientific Reports 10. 10.1038/s41598-020-58743-8

483 


\section{Table $\mathbf{1}$ (on next page)}

Shows mean divergences among groups of Scapholeberis

Estimates of evolutionary divergence over sequence pairs between groups. Standard error estimates are shown above the diagonal . A) S. armata group North America; B)

Scapholeberis sp. USA and Canada; C) S. mucronata Northern Europe; D) S. rammneri Israel;

E) S. mucronata Kaban Lakes; F) Scapholeberis sp. Churchill; G) S. freyi Gulf of Mexico; H) S. duranguensis; I) Scapholeberis sp. Chihuahua; Mexico; J) S. yahuarcaquensis n. sp.; K) S. rammneri Spain. 


\begin{tabular}{c|ccccccccccc} 
& $\mathrm{A}$ & $\mathrm{B}$ & $\mathrm{C}$ & $\mathrm{D}$ & $\mathrm{E}$ & $\mathrm{F}$ & $\mathrm{G}$ & $\mathrm{H}$ & $\mathrm{I}$ & $\mathrm{J}$ & $\mathrm{K}$ \\
\hline $\mathrm{A}$ & & 0.021 & 0.023 & 0.020 & 0.022 & 0.022 & 0.022 & 0.018 & 0.023 & 0.022 & 0.025 \\
$\mathrm{~B}$ & 0.212 & & 0.025 & 0.022 & 0.023 & 0.024 & 0.015 & 0.015 & 0.010 & 0.020 & 0.023 \\
$\mathrm{C}$ & 0.244 & 0.275 & & 0.025 & 0.022 & 0.019 & 0.027 & 0.023 & 0.027 & 0.025 & 0.025 \\
$\mathrm{D}$ & 0.182 & 0.225 & 0.269 & & 0.025 & 0.025 & 0.025 & 0.023 & 0.024 & 0.025 & 0.026 \\
$\mathrm{E}$ & 0.244 & 0.248 & 0.185 & 0.248 & & 0.017 & 0.024 & 0.023 & 0.024 & 0.024 & 0.026 \\
$\mathrm{~F}$ & 0.248 & 0.262 & 0.161 & 0.259 & 0.132 & & 0.024 & 0.023 & 0.023 & 0.024 & 0.027 \\
$\mathrm{G}$ & 0.218 & 0.141 & 0.283 & 0.249 & 0.242 & 0.257 & & 0.015 & 0.015 & 0.019 & 0.023 \\
$\mathrm{H}$ & 0.185 & 0.136 & 0.263 & 0.233 & 0.248 & 0.260 & 0.134 & & 0.015 & 0.019 & 0.021 \\
$\mathrm{I}$ & 0.231 & 0.068 & 0.289 & 0.229 & 0.249 & 0.246 & 0.121 & 0.128 & & 0.022 & 0.024 \\
$\mathrm{~J}$ & 0.223 & 0.188 & 0.265 & 0.262 & 0.263 & 0.238 & 0.164 & 0.187 & 0.184 & & 0.021 \\
$\mathrm{~K}$ & 0.268 & 0.233 & 0.271 & 0.268 & 0.274 & 0.289 & 0.208 & 0.220 & 0.229 & 0.208 &
\end{tabular}


Figure 1

SEM photographs of Scapholeberis yahuarcaquensis n.sp. from near San Antonio village, Quebrada Yahuarcaca.

A. Adult parthenogenetic female, arrow points sclerotized ridge; B. Ephippial mature female;

C. Immature female; D. Immature female; E. Head, adult; F. Frontal view showing the frontal head pore; G. Close view of the frontal head pore in D; H. Immature female, pore and A1. 


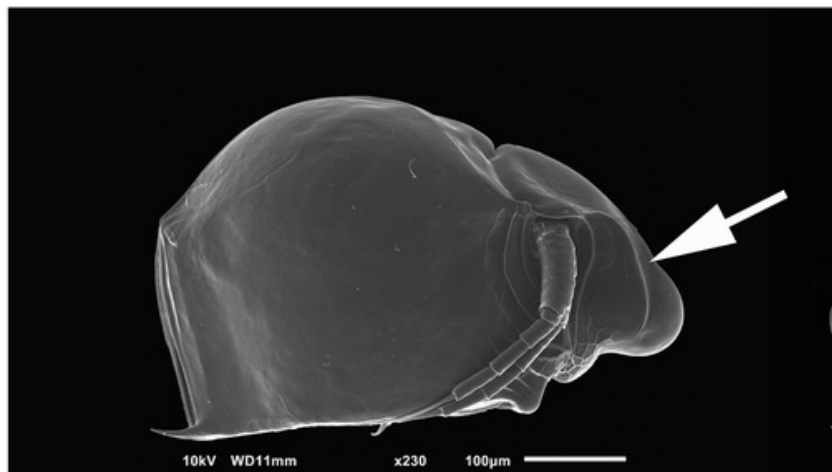

A

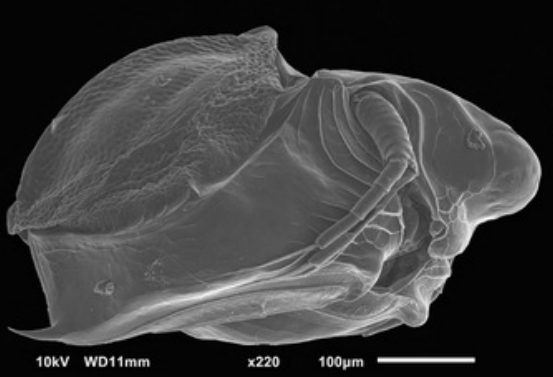

B

C
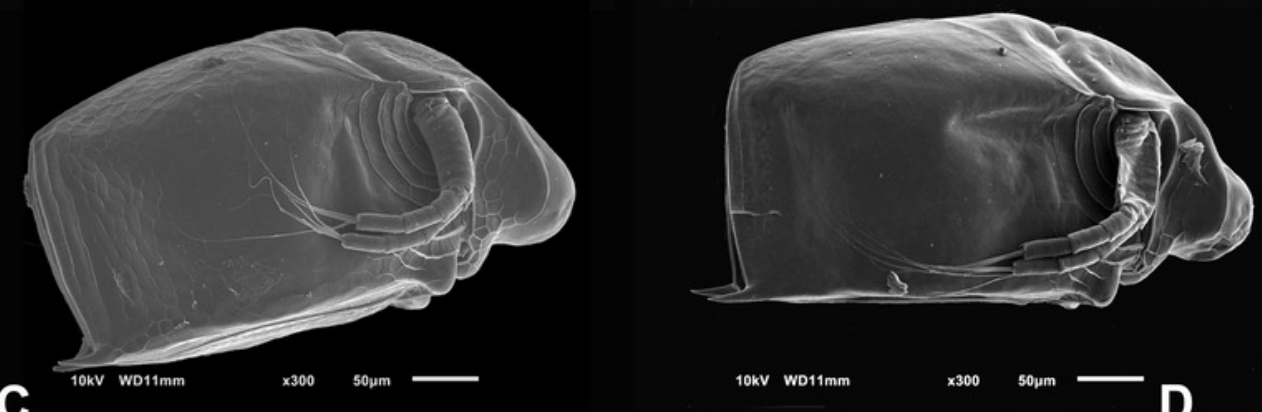

10kV WD11mm

$\times 300$

D

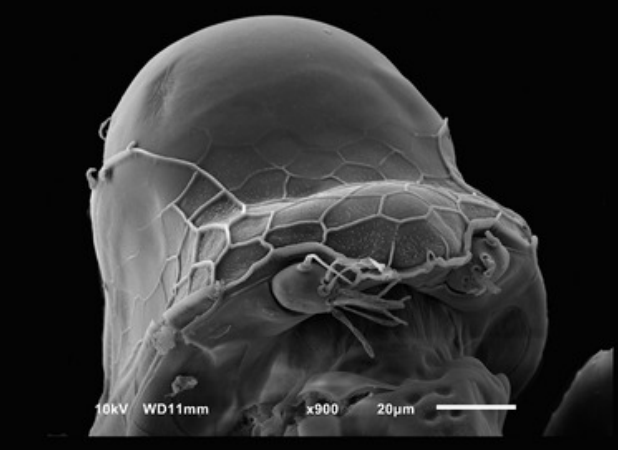

E

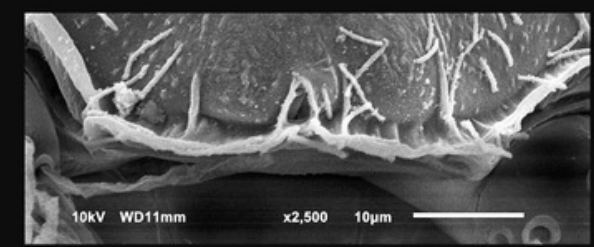

G

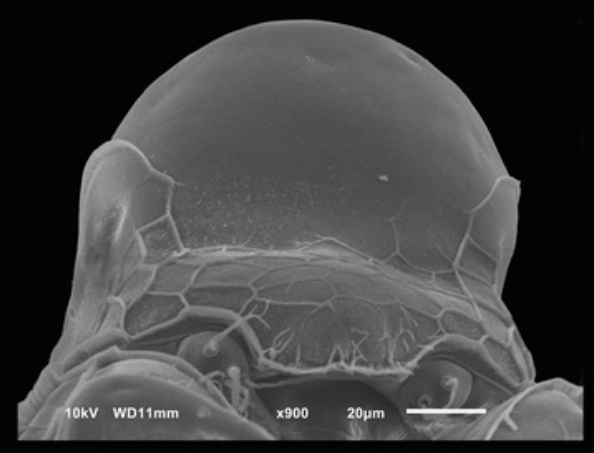

$\mathbf{F}$

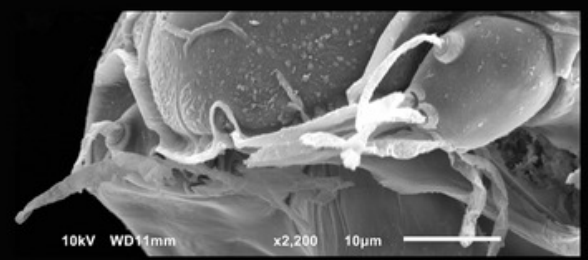

H 


\section{Figure 2}

A-B SEM photographs of Scapholeberis yahuarcaquensis n.sp. from Tracacha Renaco, Quebrada Yahuarcaca. C-E SEM photographs of Scapholeberis yahuarcaquensis n.sp. from near San Antonio village, Quebrada Yahuarcaca.

A. Parthenogenetic female, dorsal view showing pore position in one side (arrow); B. Close view of the pore; C. Close view of the seta in the hyaline lamella. Arrow points its location in posterior margin; D. Internal view of the hyaline lamella along the posterior margin of the valve; E. Close view of the origin of the hyaline lamella, near the mucro. 


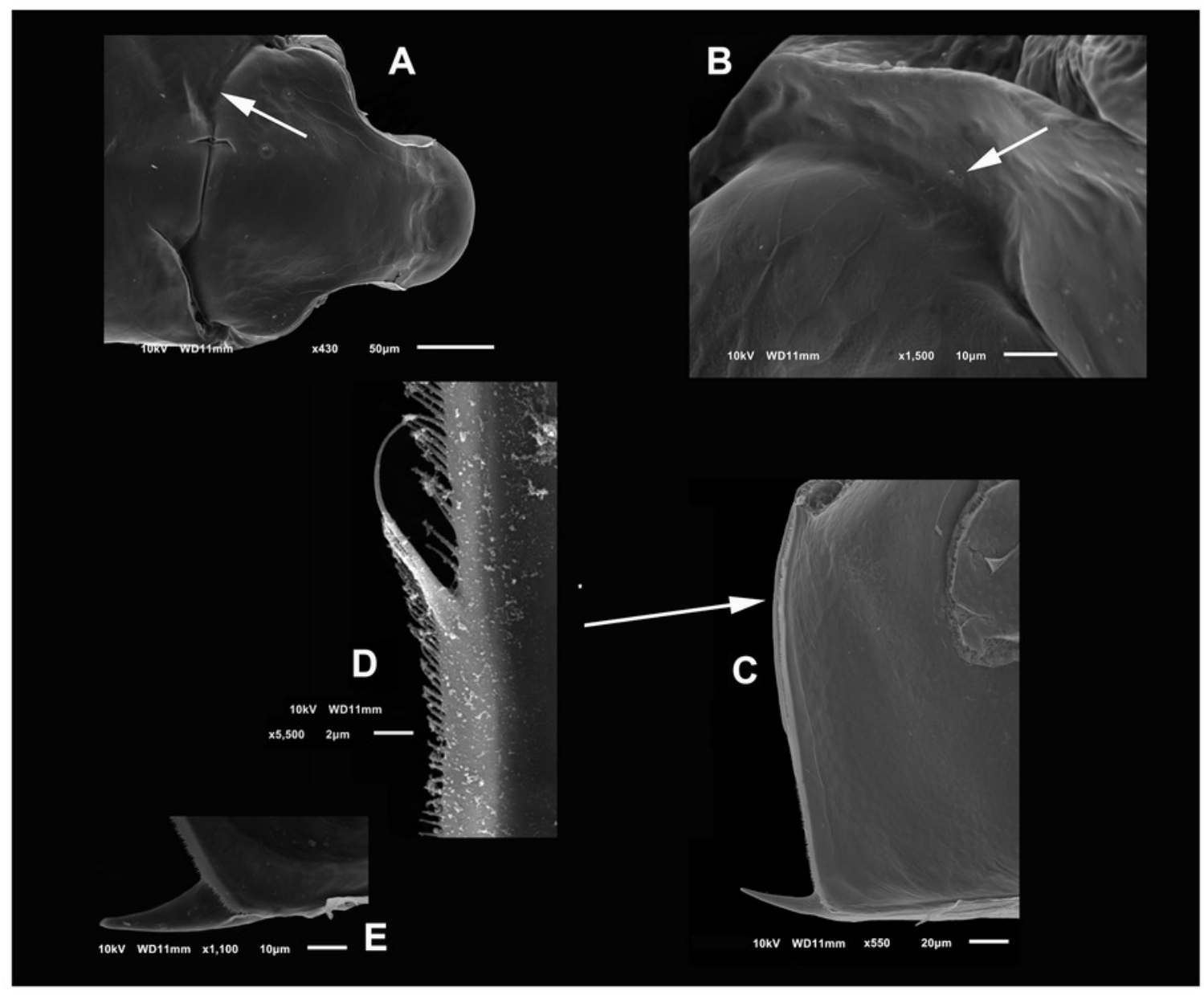




\section{Figure 3}

SEM photographs of the ventral sucker of Scapholeberis yahuarcaquensis n.sp. from near San Antonio village, Quebrada Yahuarcaca.

Arrows point to the enlarged region of the sucker from the ventral view of a mature parthenogenetic female (A); B. Lamellae in posterior part; C. Lamellae in the middle part; D. Lamellae in the anterior part E. Denticled lamellae in the posterior third; F. Lamellae in the outer side in the middle part of the sucker; G. Close view of the whole sucker. 


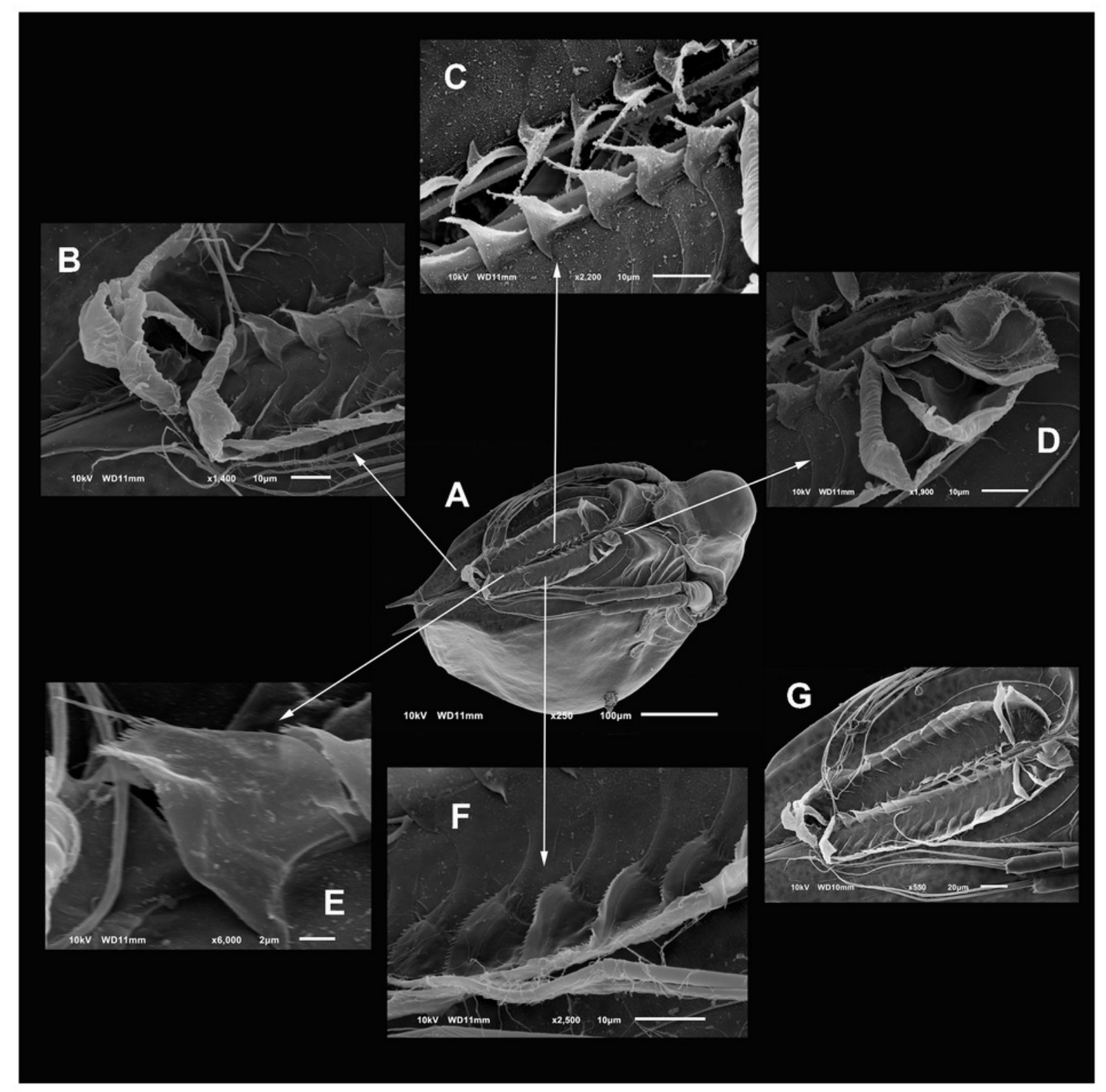


Figure 4

SEM photographs of Scapholeberis yahuarcaquensis n.sp. from near San Antonio village, Quebrada Yahuarcaca.

A.- Close view of the rostrum and A1; B. Basipodite and two setae near the external base; C. General view of the A2; D. Distal side of the basipod, with finger-like projection and the seta emerging from a pore; E. Labrum; F. Limb I, arrow points to the brush-shaped seta. 


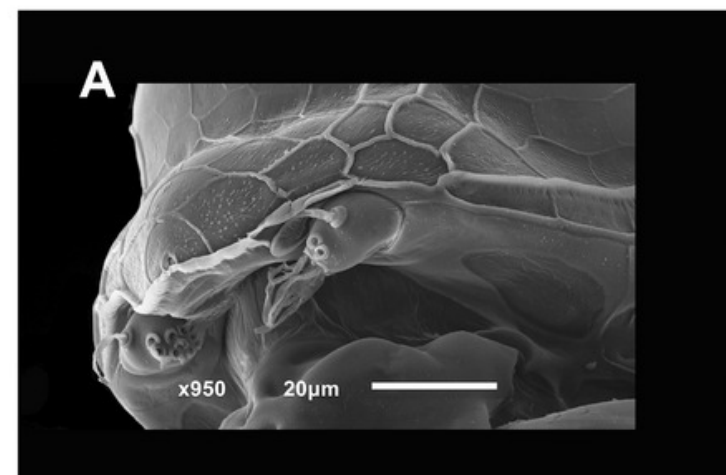

B

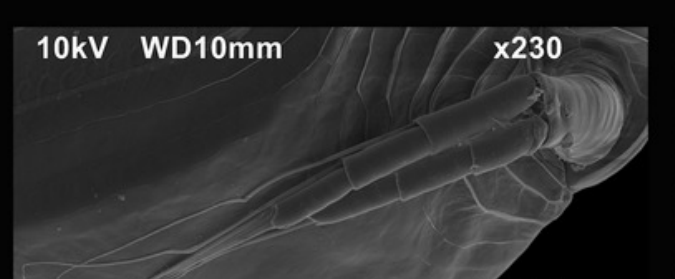

$100 \mu \mathrm{m}$

C
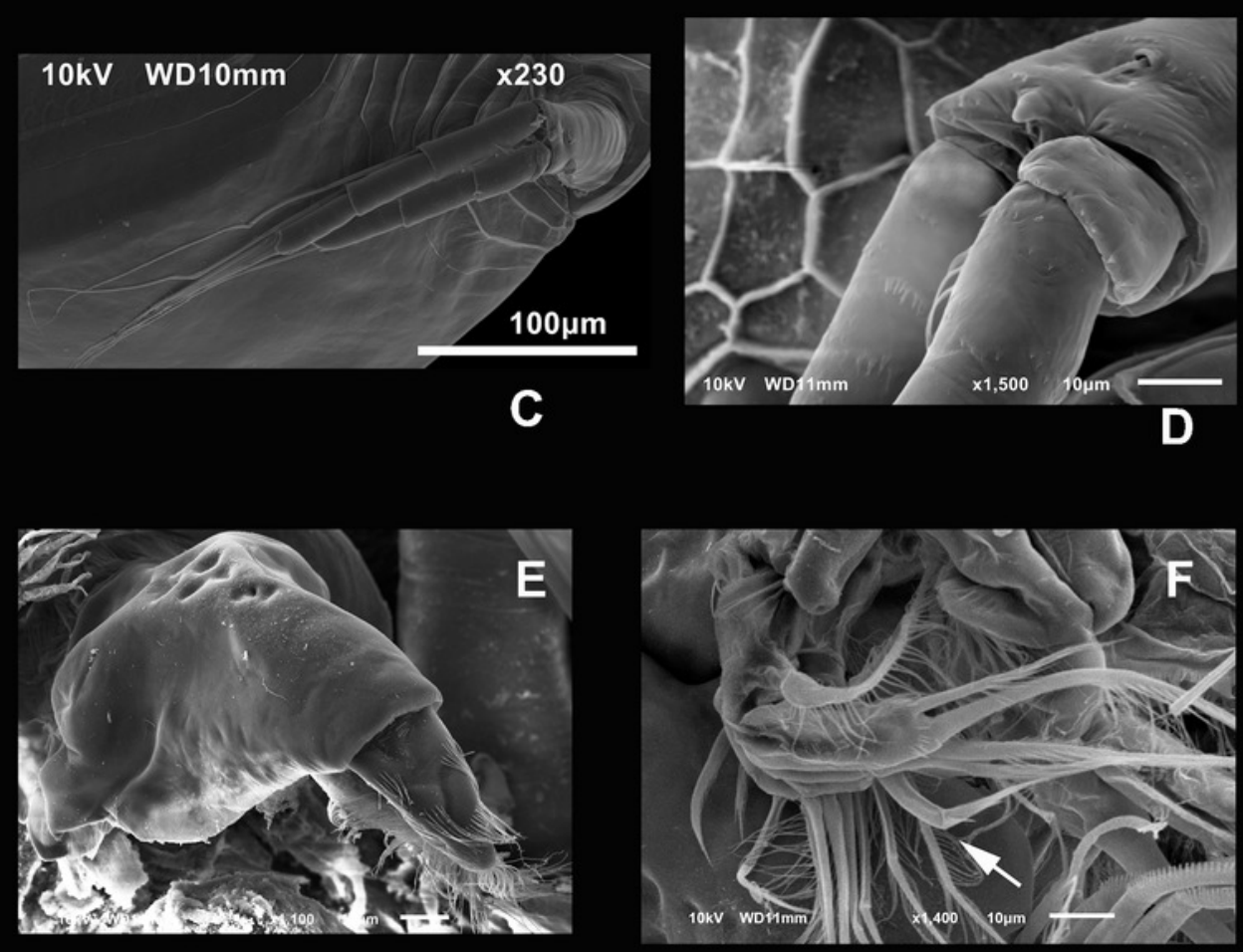
Figure 5

SEM photographs of Scapholeberis yahuarcaquensis n.sp. from near San Antonio village, Quebrada Yahuarcaca.

A. P2, exopodite and part of the endopodite; B. distal side of postabdomens and claws; C. Dorsal view of the postabdomen, postanal region; D. Dorsal process in the postabdomen; $\mathrm{E}$. Claws, arrow points to the isolated spines in the inner margin. 


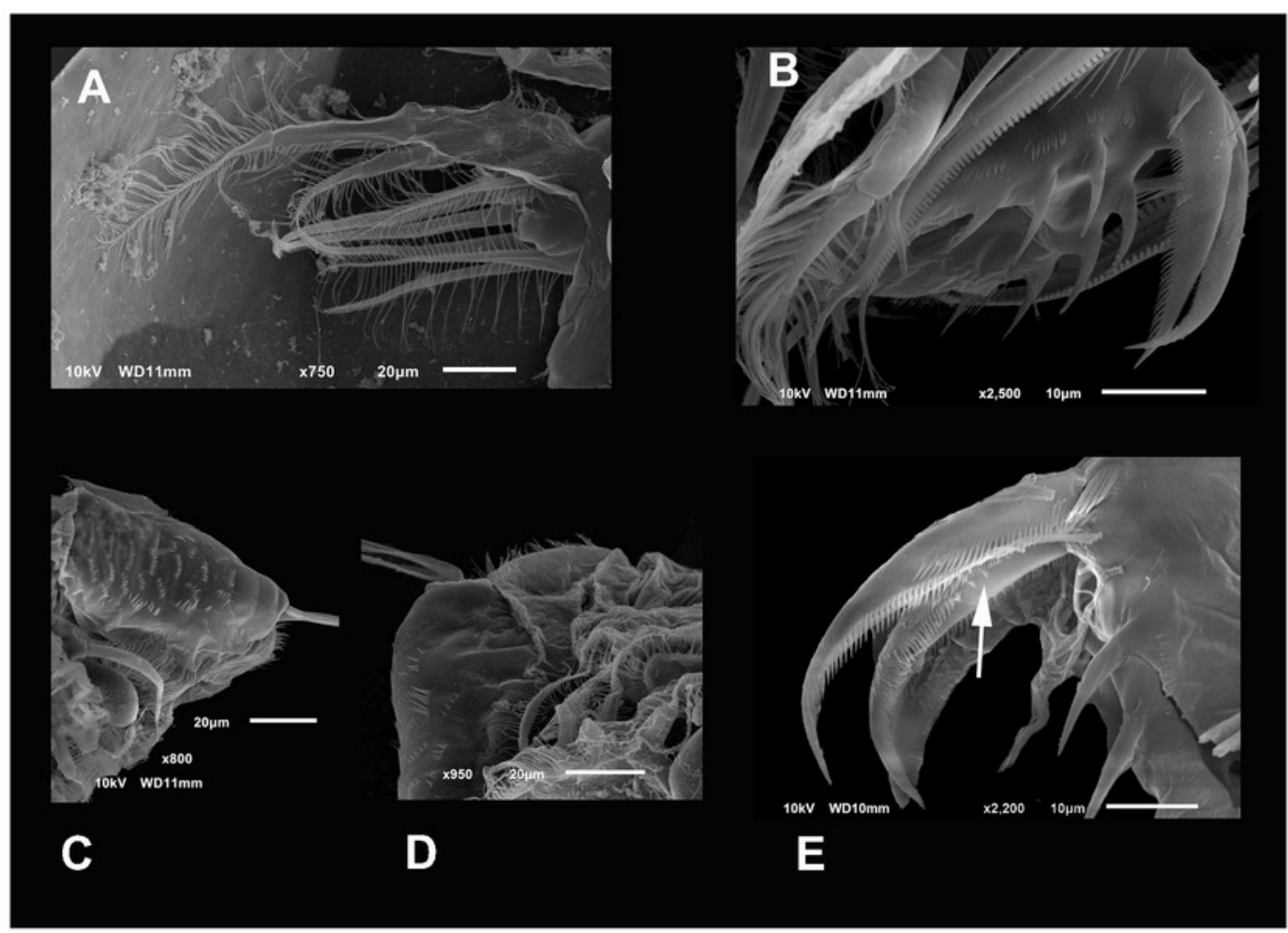




\section{Figure 6}

SEM photographs of Scapholeberis yahuarcaquensis n.sp. from Tracacha Renaco, Quebrada Yahuarcaca, Male.

A. Ventral view, arrow points to long lamellae from the anterior part of the sucker; B. Close view of the rostrum and A1; C. Arrangement of the limbs, in the left side the well-developed hooks of P1 are visible; D. Close view of the male hook and the pad (body of endopodite). Arrow points the triangle-like lamellae on the basis of the hook; E. Ventral view of the postabdomen; F. Claw. 


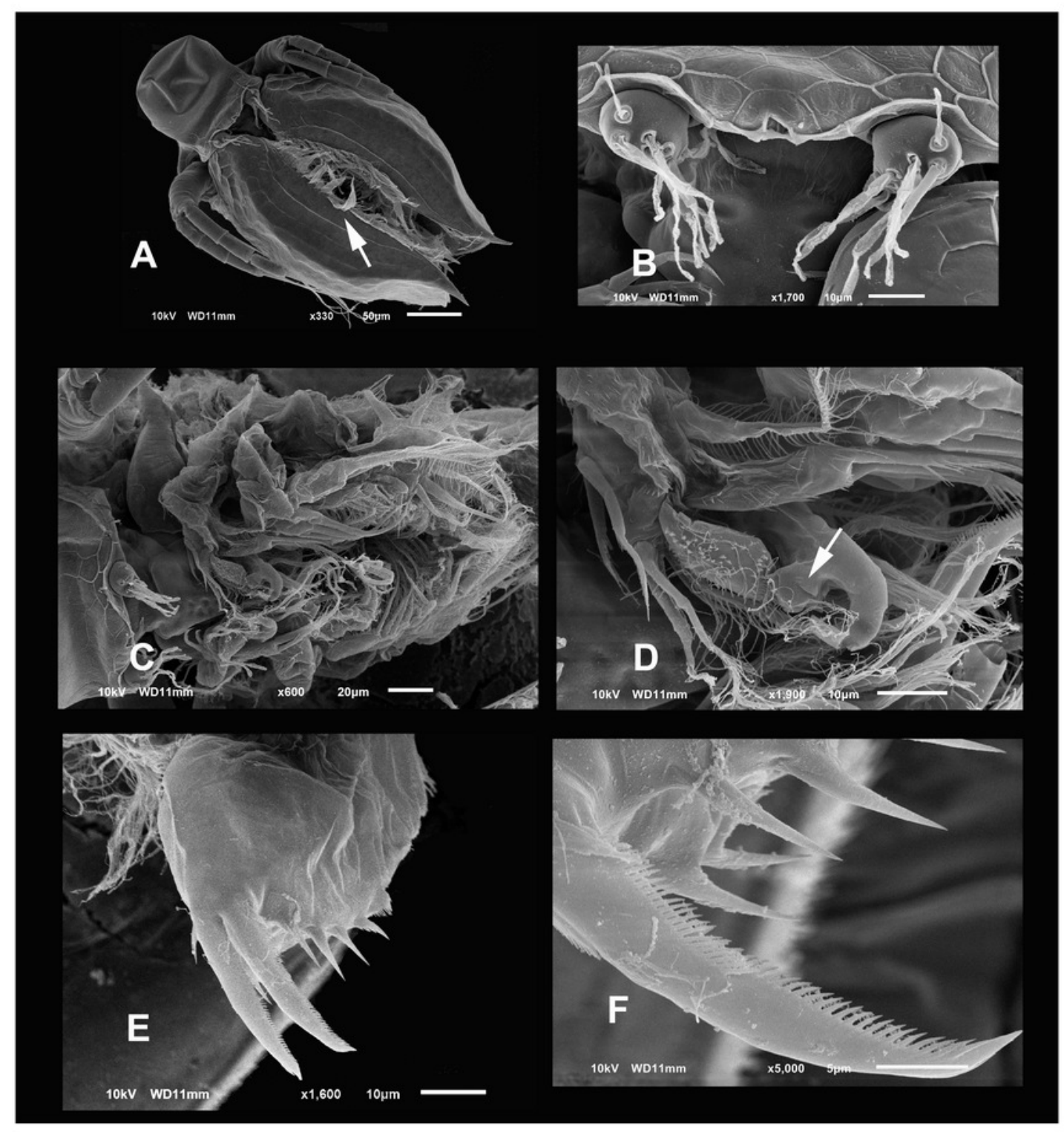


Figure 7

Scapholeberis yahuarcaquenis n. sp. from Quebrada Yahuarcaca, near village San Antonio.

A. trunk limb I; B. trunk limb II; C. Trunk limb III; D. trunk limb IV. E. Trunk limb V. Initials:

$\mathrm{EN}=$ endopod, $\mathrm{EX}=$ exopod, $\mathrm{E}=$ endite, $\mathrm{GN}=$ gnathobase, $\mathrm{BS}=$ =brush-shaped setae. 


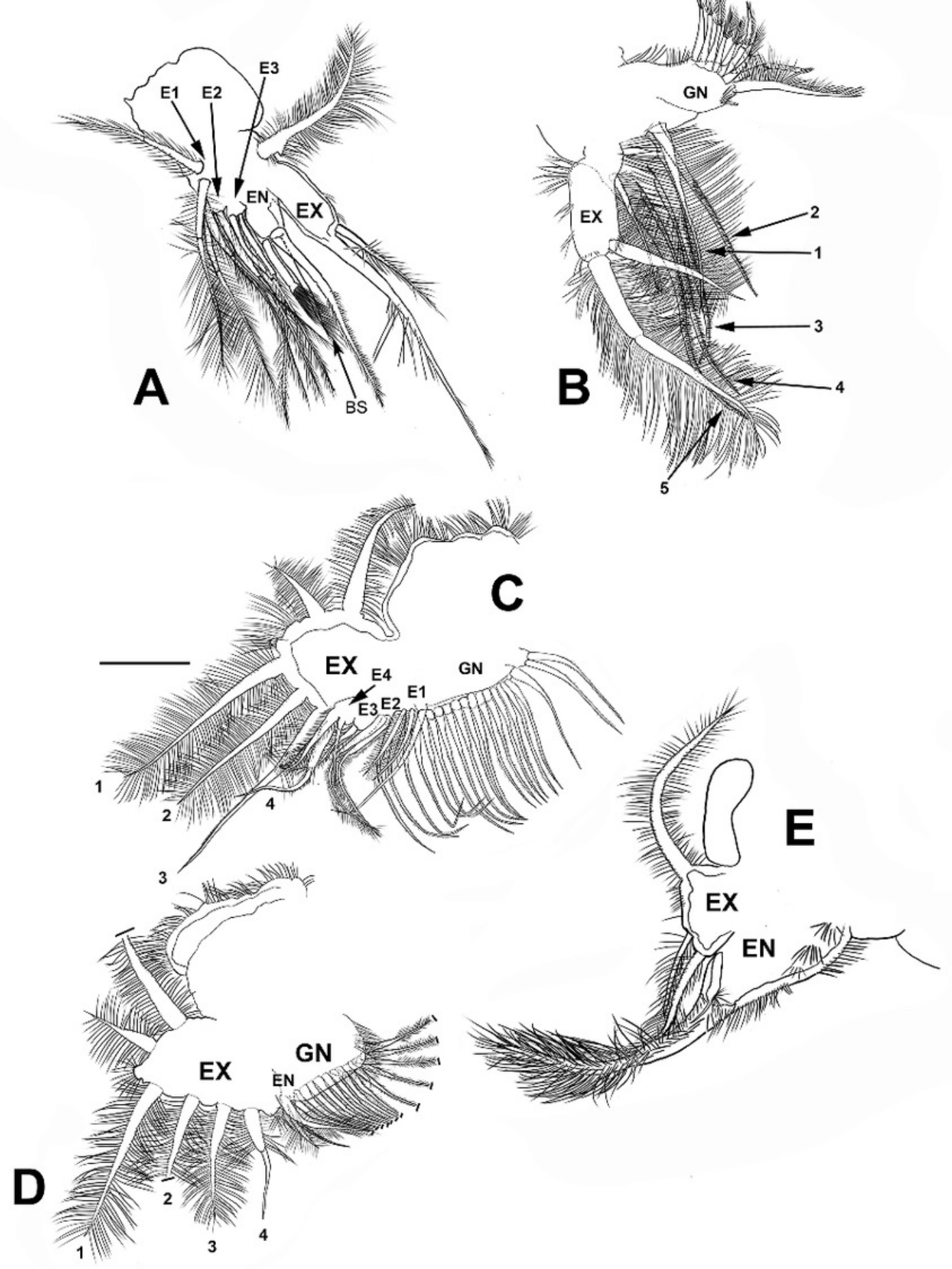




\section{Figure 8}

Bayesian tree after the molecular analysis of the COI gene comparing the known sequences for Scapholeberis in BOLD.

Names and interim names are as they appear in the databases. In brackets is shown the place of collection and the BIN number given by BOLD system.

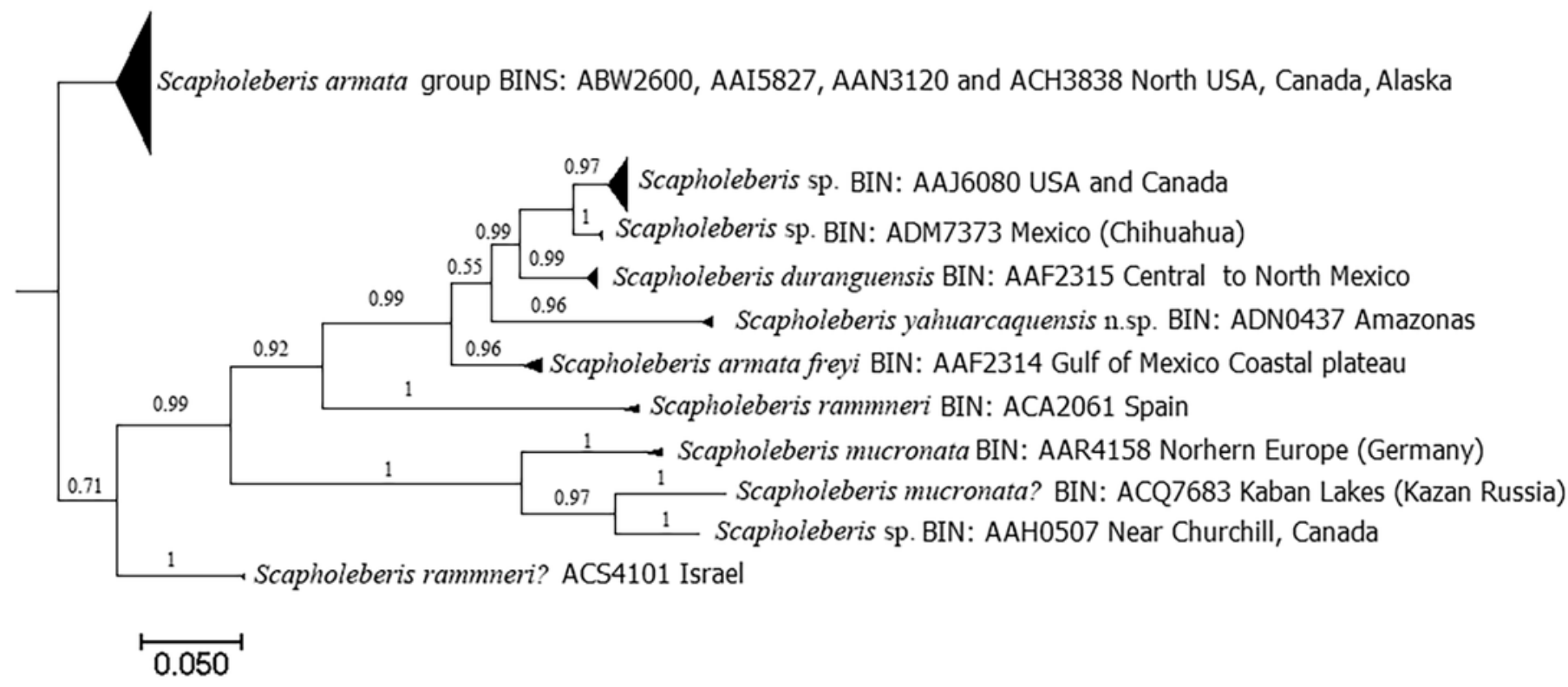

